Article

\title{
Expanding the Scope of Cu(I) Catalyzed "Click Chemistry" with Abnormal NHCs: Three-Fold Click to Tris-Triazoles
}

\author{
Nga Kim T. Ho ${ }^{1,2}$, Sven O. Reichmann ${ }^{3}$, Dennis Rottschäfer ${ }^{1,2} \mathbb{B}^{(\mathbb{O}}$, Regine Herbst-Irmer ${ }^{3}$ and \\ Rajendra S. Ghadwal 1,2,* (iD) \\ 1 Anorganische Molekülchemie und Katalyse, Lehrstuhl für Anorganische Chemie und Strukturchemie, \\ Fakultät für Chemie, Universität Bielefeld, Universitätsstraße 25, D-33615 Bielefeld, Germany; \\ ho@uni-bielefeld.de (N.K.T.H.); dennis.rottschaefer@uni-bielefeld.de (D.R.) \\ 2 Centrum für Molekulare Materialien, Fakultät für Chemie, Universität Bielefeld, Universitätsstraße 25, \\ D-33615 Bielefeld, Germany \\ 3 Institut für Anorganische Chemie der Georg-August-Universität Göttingen, Tammannstraße 4, \\ D-37077 Göttingen, Germany; sreichmann@chemie.uni-goettingen.de (S.O.R.); \\ rherbst@shelx.uni-ac.gwdg.de (R.H.-I.) \\ * Correspondence: rghadwal@uni-bielefeld.de; Tel.: +49-521-108-6167
}

Received: 10 August 2017; Accepted: 28 August 2017; Published: 1 September 2017

\begin{abstract}
Cationic copper(I) complexes $\left[\mathrm{Cu}\left(\mathrm{aIPr}^{\mathrm{Ph}}\right)(\mathrm{IPr})\right] \mathrm{I}(3)$ and $\left[\mathrm{Cu}\left(\mathrm{aIPr} \mathrm{Ph}_{2}\right] \mathrm{I}\right.$ (4) featuring an abnormal $N$-heterocyclic carbene (aNHC) $(\mathrm{aIPr} P h=1,3-b i s(2,6$-diisopropylphenyl)-2-phenylimidazol-4-ylidene) and/or an NHC (IPr = 1,3-Bis(2,6-diisopropylphenyl)imidazol-2-ylidene) ligand(s) are reported. Treatment of $\mathrm{Cu}\left(\mathrm{aIPr}{ }^{\mathrm{Ph}}\right) \mathrm{I}(2)$ with $\mathrm{IPr}$ affords complex 3 . Reaction of (IPrPh)I (1) (IPrPh = 1,3-bis(2,6-diisopropylphenyl)-2-phenyl-imidazolium) with CuI in the presence of $\mathrm{K}\left\{\mathrm{N}\left(\mathrm{SiMe}_{3}\right)_{2}\right\}$ leads to the formation of 4 . Complexes 3 and 4 represent rare examples of mixed aNHC-NHC and bis-aNHC metal complexes, respectively. They are characterized by elemental analysis, NMR spectroscopic, and mass spectrometric studies. The solid-state molecular structures of $\mathbf{3}$ and 4 have been determined by single crystal X-ray diffraction analyses. The catalytic activity of $\mathbf{2}$, 3 , and 4 has been investigated in the [3+2] cycloaddition of alkynes and organic azides, affording triazole derivatives in an almost quantitative yield. Notably, complexes 2, 3, and 4 are excellent catalysts for the three-fold cycloaddition of a tris-azide with various alkynes. This catalytic protocol offers a high yield access to tris-triazoles in a shorter reaction time and considerably reduces the experimental work-up compared to the classical synthetic method.
\end{abstract}

Keywords: abnormal carbene; click reaction; copper; [3+2] cycloaddition; $N$-heterocyclic carbene; tris-triazoles; structure; catalysis

\section{Introduction}

$\mathrm{N}$-Heterocyclic carbenes (NHCs) are an important class of carbon-donor neutral ligands in organometallic chemistry and catalysis [1-6]. The versatility of NHCs is manifested in a variety of transition metal-mediated chemical transformations [7-13] as well as in the stabilization of a variety of fascinating molecular compounds featuring low-valent main group elements [14-17]. The success of the NHC-metal partnership (I, Chart 1) in catalysis and beyond is largely attributed to the strong $\sigma$-donor ability of NHCs, resulting in the formation of a rather robust $\mathrm{M}-\mathrm{C}_{(\mathrm{NHC})}$ bond. This has also prompted further interests in the development of different types of carbon-donor ligands with improved donor-acceptor properties [18-23]. A new type of NHCs (II, Chart 1) that bind to metals at the imidazol-backbone (i.e., at the C4- or C5-atom) is of a special significance [22,24-32] because experimental and theoretical data suggest that these so-called abnormal NHCs (aNHCs) 
(II) are stronger $\sigma$-donors than classical NHCs (I) as well as Bertrand's CAACs (cyclic alkyl amino carbenes) $[21,33,34]$. Classical NHCs (I) are also referred as C2-carbenes or Arduengo's carbenes. As no neutral canonical form without the introduction of formal charges can be written, aNHCs (II) are sometimes also described as mesoionic carbenes (MICs) [35]. In 2001, Crabtree et al. [32] reported, albeit as a result of serendipitous product, the first aNHC-complex. In 2009, Bertrand and co-workers reported the first stable metal-free aNHC [27]. Though most of the aNHC-metal complexes (II) reported so far were isolated as serendipitous products [22,36], they exhibit excellent catalytic activity, which in many cases surpasses that of their normal counterparts under similar experimental conditions [21,22,30,37-42]. Therefore, the development of new synthetic methods to aNHC-complexes $[43,44]$ is highly desired to further foster their applications in catalysis and beyond [36]. We recently reported the direct C2-arylation of an NHC using a palladium catalyst to give C2-arylated imidazolium salts $[45,46]$, which are found to be suitable precursors to different aNHC-metal complexes [45-49].

The copper-catalyzed alkyne-azide cycloaddition (CuCAAC) reaction (also known as Huisgen 1,3-dipolar cycloaddition) [50-54] represents the flagship transformation of "Click Chemistry" that has found remarkable applications in organic synthesis $[55,56]$, coordination chemistry $[57,58]$, and material science [59-62]. In general, any $\mathrm{Cu}(\mathrm{I})$ source can be used as a catalyst, however, the application of well-defined $\mathrm{Cu}(\mathrm{I})$-complexes offers several advantages, including the ease with mechanistic studies, selectivity, low-catalyst loading, and milder reaction conditions [63-65].<smiles></smiles>

(I)<smiles></smiles>

(II)

NHC-metal complex aNHC (or MIC) -metal complex

Chart 1. NHC- (I) and aNHC- (or MIC) (II) complexes.

NHC-Cu(I) complexes have been extensively investigated in CuCAAC reactions [43,44,63,65-71]. Compounds of a general formula $\mathrm{Cu}(\mathrm{NHC}) \mathrm{X}(\mathrm{A})$ (Chart 2) are among the most widely explored $\mathrm{Cu}(\mathrm{I})$ catalysts $[43,63,69,71,72]$. However, analogs compounds featuring a 1,3-imidazol-derived aNHC (C) are very scarce $[43,44,73-75]$. Similarly, only a handful of other transition metal complexes featuring mixed NHC-aNHC ligands are known [76-85]. Nolan et al. reported cationic copper complexes $\left[\mathrm{Cu}(\mathrm{NHC})_{2}\right] \mathrm{X}(\mathbf{B}, \mathrm{Chart} 2)$ which exhibit enhanced activity in the CuCAAC reactions compared to A [65], however analogous derivatives such as $\mathbf{D}$ containing aNHCs have remained so far unknown. Cazin et al. [86,87] investigated heteroleptic $\mathrm{Cu}(\mathrm{I})$ complexes $\left[\mathrm{Cu}(\mathrm{NHC})\left(\mathrm{NHC}^{\prime}\right)\right] \mathrm{X}$ featuring dissimilar Arduengo-type NHCs, but heteroleptic compounds such as $[\mathrm{Cu}(\mathrm{NHC})(\mathrm{aNHC})] \mathrm{X}(\mathrm{E})$ featuring a normal as well as an abnormal NHC are remained so far unexplored.

We report herein the synthesis and characterization of two new cationic copper complexes, $\left[\mathrm{Cu}\left(\mathrm{aIPr}^{\mathrm{Ph}}\right)_{2}\right] \mathrm{I}(3)$ and $\left[\mathrm{Cu}\left(\mathrm{aIPr}{ }^{\mathrm{Ph}}\right)(\mathrm{IPr})\right] \mathrm{I}(4)$, featuring 1,3-imidazol-derived carbenes $\left(\mathrm{aIPr}^{\mathrm{Ph}}=1,3-\right.$ bis(2,6-diisopropylphenyl)-2-phenyl-imidazol-4-ylidene; $\operatorname{IPr}=1,3$-bis(2,6-diisopropylphenyl)-imidazol2-ylidene). The catalytic activity of complexes $\mathrm{Cu}\left(\mathrm{aIPr}^{\mathrm{Ph}}\right) \mathrm{I}(2)$ [45], 3, and 4 has been examined in CuCAAC reactions to yield various triazoles. Tris-triazoles are important ligands in coordination chemistry $[57,58,88,89]$ and serve as building blocks for the preparation of multitopic triazole-based aNHC compounds [90,91]. Interestingly, compounds $\mathbf{2}, \mathbf{3}$, and $\mathbf{4}$ are also found to be excellent catalysts for the cycloaddition of tris-azides with alkynes, leading to the formation of tris-triazoles in an excellent yield. 
<smiles></smiles>

(I)

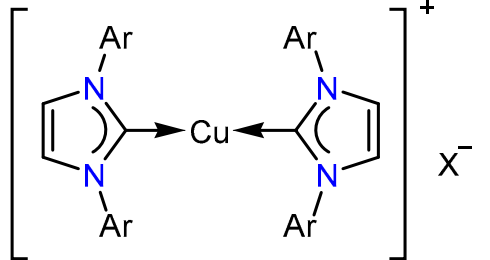

$\mathrm{X}=\mathrm{BF}_{4}$ or $\mathrm{PF}_{6}$

B

Nolan et al., 2008

Cazin et al., 2012

Nolan et al., 2006 $(\mathrm{Ar}=$ aryl group $)$

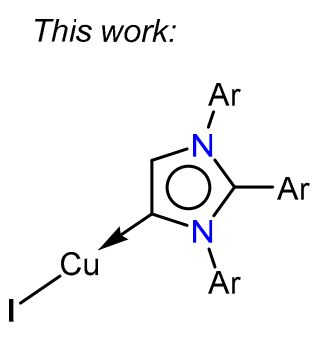

C

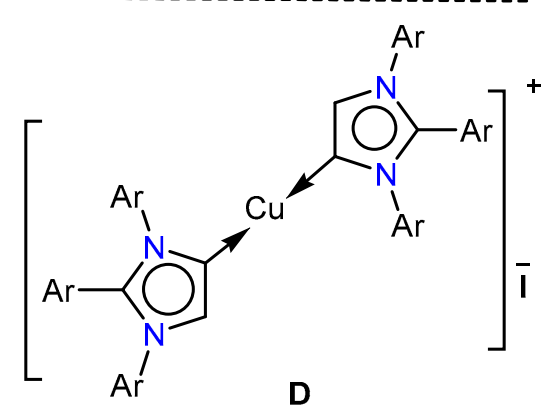

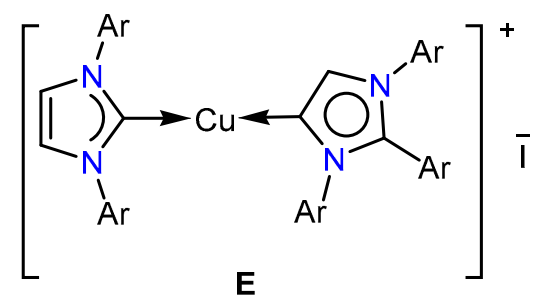

Chart 2. Neutral $\mathrm{Cu}(\mathrm{NHC}) \mathrm{X}(\mathbf{A})$ and cationic $\left[\mathrm{Cu}(\mathrm{NHC})_{2}\right] \mathrm{X}(\mathbf{B})$ compounds and their aNHC-counterparts (C-E).

\section{Results and Discussion}

\subsection{Synthesis}

Treatment of a THF suspension of (IPrPh)I (1) and CuI with one eq of potassium hexamehtyldisilazide (KHMDS) (Scheme 1) leads to the formation of complex Cu(aIPr $\left.{ }^{\mathrm{Ph}}\right) \mathrm{I}(\mathbf{2})(91 \%)$ [45]. Reaction of compound $\mathbf{2}$ with one equivalent of free IPr cleanly affords the heteroleptic copper complex $\left[\mathrm{Cu}\left(\mathrm{aIPr}{ }^{\mathrm{Ph}}\right)(\mathrm{IPr})\right] \mathrm{I}(3)(81 \%)$, containing both aNHC and NHC ligands. Similarly, treatment of a mixture of 1 and $\mathrm{CuI}$ in a 2:1 molar ration with two equivalents of KHMDS gives the complex [( $\left(\mathrm{IPr} P{ }_{2} \mathrm{Cu}\right]$ (4) $(40 \%)$. Compounds 2, 3, and 4 are colorless crystalline solids that are stable under an inert gas atmosphere.

\subsection{Characterization}

Compounds 3 and 4 have been characterized by elemental analyses, ${ }^{1} \mathrm{H}$ and ${ }^{13} \mathrm{C} N \mathrm{NMR}$ spectroscopy, and mass spectrometry. In addition, the solid-state molecular structures of 3 (Figure 1) and 4 (Figure 2) have been unequivocally determined by single crystal $\mathrm{X}$-ray diffraction analyses. The ESI mass spectrum of each of $3(915.5 \mathrm{amu})$ and $4(991.6 \mathrm{amu})$ shows the molecular ion peak that corresponds to the respective cationic moiety. As expected, the ${ }^{1} \mathrm{H}$ NMR spectrum of 3 exhibit two doublets and one septet for the isopropyl groups of IPr ligand. However, due to the lack of the C2-symmetry, the isopropyl groups of aIPr Ph ligand show four doublets, one of them overlaps with a doublet of IPr ligand, and two septets. The imidazol-backbone protons can be identified as a singlet at $\delta$ 
6.54 (for aIPr ${ }^{\mathrm{Ph}}$ ) and 7.78 (for IPr) ppm. Similarly, the ${ }^{1} \mathrm{H}$ NMR spectrum of 4 exhibits one pseudo-triplet, which arises due to two overlapping doublets, and two doublets for methyl groups along with a multiplet for the methine protons of $\mathrm{HCMe}_{2}$ groups. The imidazol-backbone protons appear as a singlet at $\delta 7.08 \mathrm{ppm}$. The ${ }^{13} \mathrm{C}$ NMR spectra of compounds 3 and 4 exhibit corresponding signals for the IPr and aIPr ${ }^{P h}$ ligands, which are consistent with their ${ }^{1} \mathrm{H}$ NMR resonances. Compound 3 exhibits ${ }^{13} \mathrm{C}$ NMR resonances for the carbene carbon atoms at $\delta 159.53\left(C_{(\mathrm{aIPrPh})}-\mathrm{Cu}\right)$ and $180.99\left(\mathrm{C}_{(\mathrm{IPr})}-\mathrm{Cu}\right)$ ppm. The ${ }^{13} \mathrm{C}$ NMR spectrum of 4 shows a signal at $\delta 161.05 \mathrm{ppm}$, which can be assigned for the abnormal carbene carbon atom $\left(C_{(\mathrm{aIPrPh})}-\mathrm{Cu}\right)$.<smiles></smiles>
1 \begin{tabular}{l|l}
$\mathrm{THF}$ \\
$0^{\circ} \mathrm{C} \downarrow$ \\
$+\mathrm{KN}\left(\mathrm{SiMe}_{3}\right)_{2}$ \\
$+0.5 \mathrm{eq} \mathrm{Cul}$
\end{tabular}

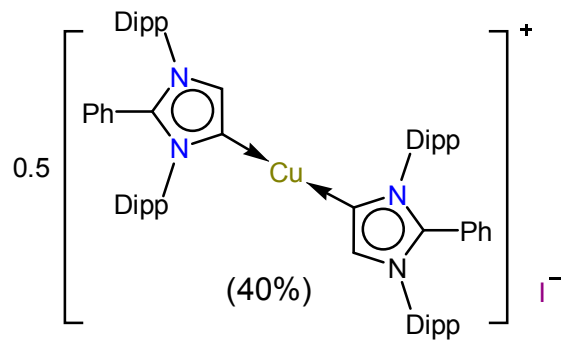

4

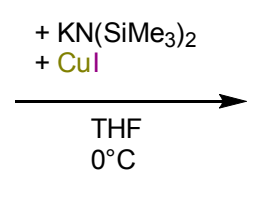

(Dipp = 2,6-diisopropylphenyl)<smiles>c1ccccc1</smiles>

2

toluene $\downarrow+\operatorname{IPr}$

Scheme 1. Synthesis of aNHC-Cu(I) complexes 2, 3, and 4 .

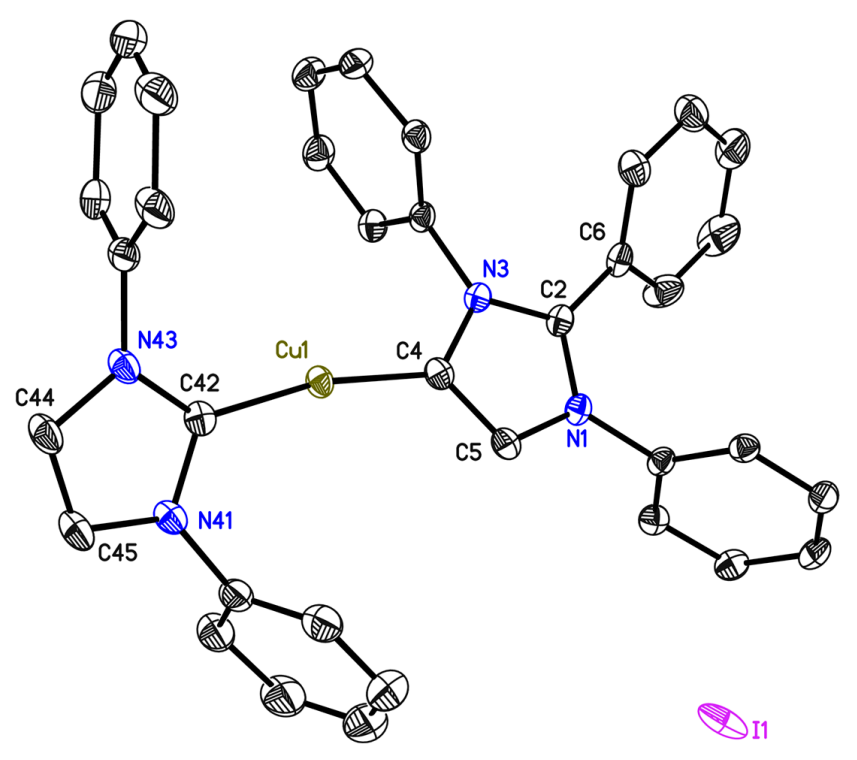

Figure 1. Molecular structure of $\left[\mathrm{Cu}\left(\mathrm{aIPr}^{\mathrm{Ph}}\right)(\mathrm{IPr})\right] \mathrm{I}$ (3). Anisotropic displacement parameters are depicted at the 50\% probability level. Hydrogen atoms and isopropyl groups are omitted for clarity. Selected bond lengths $(\AA)$ and bond angles $\left({ }^{\circ}\right)$ : C42-Cu1, 1.9041(19); C4-Cu1, 1.9005(19); C4-C5, 1.365(3); C44-C45, 1.341(3); C42-Cu1-C4, 168.45(9); N43-C42-N41, 104.06(16); N43-C44-C45, 107.44(18); N3-C4-C5, 102.99(16); N3-C2-N1, 106.49(16). 


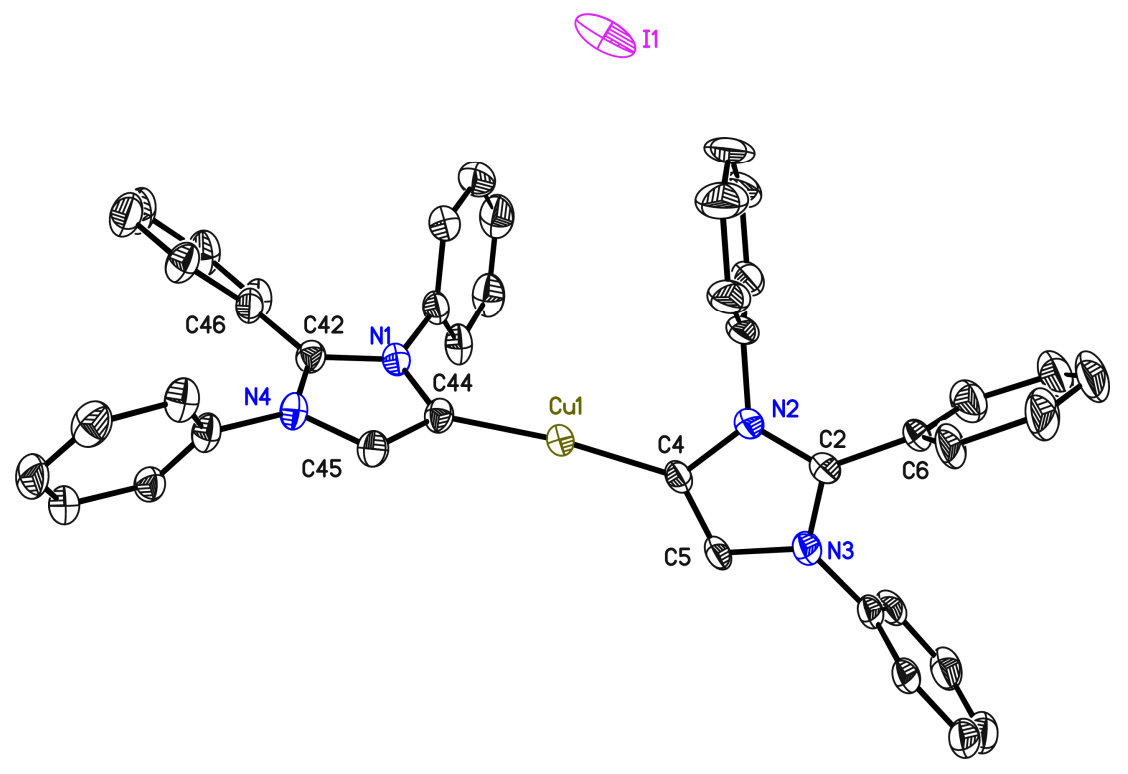

Figure 2. Molecular structure of $\left[\mathrm{Cu}\left(\mathrm{aIPr}^{\mathrm{Ph}}\right)_{2}\right] \mathrm{I}(4)$. Anisotropic displacement parameters are depicted at the $50 \%$ probability level. Hydrogen atoms and isopropyl groups are omitted for clarity. Selected bond lengths $(\AA)$ and bond angles $\left({ }^{\circ}\right)$ : C44-Cu1, 1.914(3); C4-Cu1, 1.914(3); C4-C5, 1.356(4); C44-C45, 1.363(4); C44-Cu1-C4, 172.66(12); N1-C42-N4, 106.3(2); N2-C4-C5, 102.7(2); N3-C2-N2, 107.4(3).

The molecular structure of 3 (Figure 1) features a two-fold coordinated copper atom with a considerably bent C4-Cu1-C42 bond angle of 168.45(9) ${ }^{\circ}$. The C42-Cu1 (1.9041(19) $\AA$ ) and C4-Cu1 (1.9005(19) $\AA$ ) bond lengths, respectively for the normal (IPr) and abnormal $\left(\mathrm{aIPr}^{\mathrm{Ph}}\right) \mathrm{NHC}$ are comparable. The C4-C5 (1.365(3) A) bond length of 3 is slightly longer than that of the C44-C45 (1.341(3) $\AA$ ), indicating the carbene nature of the C4-carbon atom. Similarly, the N3-C4-C5 bond angle $\left(102.99(16)^{\circ}\right)$ is smaller than the corresponding N43-C44-C45 $\left(107.41(18)^{\circ}\right)$ bond angle, highlighting the impact of the position of the carbene carbon (C4) atom on the structural coordinates. This becomes more obvious when N43-C42-N41 $\left(104.06(16)^{\circ}\right)$ and N3-C2-N1 $\left(106.49(16)^{\circ}\right)$ bond angles are compared, where only the former features a carbene carbon atom.

The molecular structure of 4 (Figure 2) features a two-coordinated copper atom with a slightly

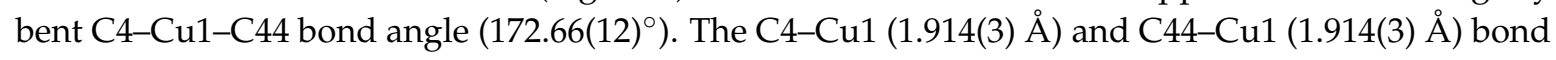
lengths are slightly longer than that of 3 , whereas other structural features are comparable with compound 3.

\subsection{Catalysis}

The reaction of phenyl acetylene and benzyl azide was chosen as a benchmark reaction for assessing the catalytic activity of compounds 2,3 , and 4 . The progress of the reaction was monitored by ${ }^{1} \mathrm{H}$ NMR spectroscopic analysis. A neat solution of benzyl azide $(1 \mathrm{mmol})$ and phenyl acetylene $(1.1 \mathrm{mmol})$ and an appropriate amount of the catalyst was stirred at room temperature. The details of catalysts screening are provided in the supporting information. Compound $\mathbf{2}$ is highly active and quantitative conversion was observed after $5 \mathrm{~min}$ with a catalyst loading of $1 \mathrm{~mol} \%$ (Table S1, entry 1 ). However, under similar experimental conditions no conversion was seen with compound 3 or 4 even after $1 \mathrm{~h}$ (Table S1, entries 5 and 6). ${ }^{1} \mathrm{H}$ NMR analysis after $5 \mathrm{~h}$ indicated $99 \%$ conversion with 3 (Table S1, entry 7), however compound 4 required $15 \mathrm{~h}$ to achieve $80 \%$ conversion (Table S1, entry 8 ). This indicates that all three compounds are active catalysts; however, 3 and 4 need a higher induction period. In order to further compare the catalytic activity of 2, 3, and 4, different alkyne substrates were treated with benzyl azide at room temperature using $1 \mathrm{~mol} \%$ of the catalyst loading. The findings clearly suggest the following reactivity order $2>3>4$. Recent studies have shown that dinuclear 
copper species are the active catalysts in the CuCAAC reactions, which can be readily generated with 2 as it features a iodide ligand as an easy leaving group [52,56,64]. Cationic [(NHC) $\left.{ }_{2} \mathrm{Cu}\right] \mathrm{X}(\mathrm{B})\left(\mathrm{X}=\mathrm{BF}_{4}\right.$ or $\mathrm{PF}_{6}$ ) [65] complexes are also active catalysts as one carbene ligand can easily undergo exchange reaction with an azide to afford the desired active catalyst. In view of the strong $\sigma$-donor ability of aNHC $\left(\mathrm{aIPr}^{\mathrm{Ph}}\right)$, the generation of mono-ligated $\left(\mathrm{aIPr}^{\mathrm{Ph}}\right) \mathrm{Cu}$ species from 4 seems demanding, and therefore rationalizes its slow reactivity due to a longer induction period in comparison with $\mathbf{2}$ and $\mathbf{3}$.

Having recognized the highest activity of 2 , we examined further cycloaddition reactions with different substrates using 2 as a precatalyst. With the lowering of the catalyst loading to 0.5 (entry 2), 0.1 (entry 3), and 0.05 (entry 4) mol \%, quantitative conversion was achieved after $5 \mathrm{~min}, 1 \mathrm{~h}$, and $3 \mathrm{~h}$, respectively (Table S1). However, only $56 \%$ conversion was reached after $4 \mathrm{~h}$ when $0.01 \mathrm{~mol} \%$ of 2 was employed, indicating diminished reactivity at further lowering of the catalyst loading. The scope of 2 with other substrates were investigated with 0.5 (TZ-1-TZ-5) and 0.05 (TZ-6-TZ-10) $\mathrm{mol} \%$ of the loading at room temperature (Scheme 2).

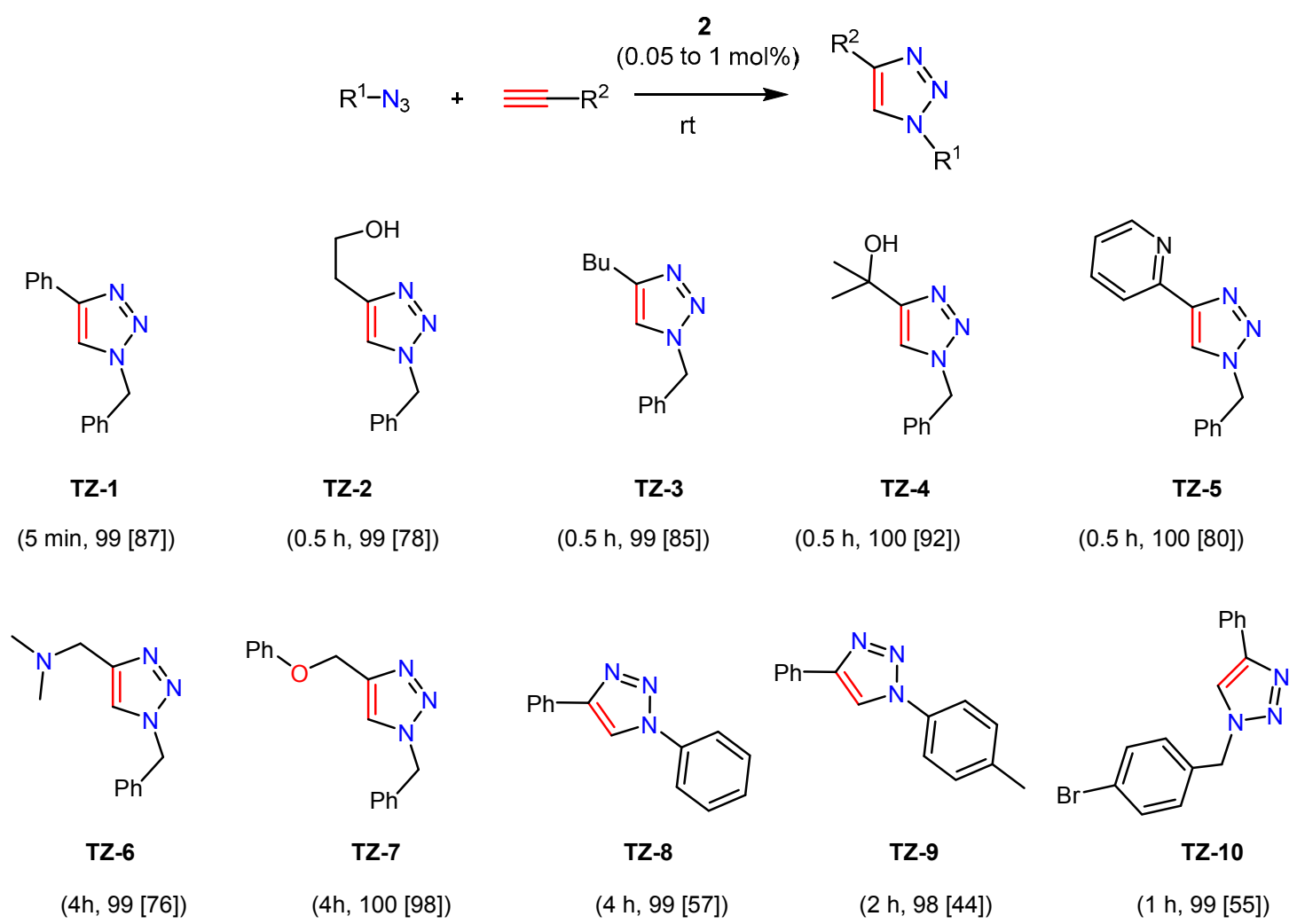

Scheme 2. Scope of the [3+2] cycloaddition of azides and alkynes with compound 2. Reaction conditions: azide $(1 \mathrm{mmol})$, alkyne $(1.1 \mathrm{mmol}), 2(1,0.5$, or $0.05 \mathrm{~mol} \%), \mathrm{rt}\left(25^{\circ} \mathrm{C}\right)$, solvent-free. Reaction time, NMR yield [Isolated yield] for triazoles TZ-1 to TZ-10.

Tris-triazoles are important building blocks in materials science and offer significant promises as ligands in coordination chemistry and catalysis [57], Note that, in comparison with simple triazoles such as TZ-1-TZ-10, synthetic protocols to tris-triazoles are quite demanding [92,93]. In general, copper sulphate $\left(\mathrm{CuSO}_{4}\right)$ is used as a pre-catalyst in the synthesis of tris-triazoles and a mixture of water and tert-butanol is the solvent of choice [58]. In the presence of a base, this reaction leads to the formation of tris-triazoles. A major drawback of this classical procedure is the elaborate experimental work-up that is required for the complete removal of residual copper contents from the product $[50,94]$. Excellent solubility and stability of $\mathbf{2 - 4}$ in dichloromethane, coupled with their high catalytic activity in standard "Click Reactions" (Scheme 2) encouraged us to probe their utility in the synthesis of tris-triazoles via the CuCAAC reaction. Interestingly, all compounds 2,3, and 4 are active catalysts and 
affords tris-triazoles via three-fold click reactions of a tris-azide with a variety of alkynes (Scheme 3). This facile procedure is more atom-economic (three-clicks with 0.5 to $1 \mathrm{~mol} \%$ of the catalyst loading) and shortens the experimental work-up without compromising the reaction outcome. The products show a negative test for the presence of copper. In a general procedure, a dichloromethane solution of a tris-azide and an alkyne is loaded with $1 \mathrm{~mol} \%$ of the catalyst and stirred at room temperature for 5 h. With the catalyst loading of $0.5 \mathrm{~mol} \%$ (Table S2, entry 2), only a slight lowering of the yield (91\%) was observed. The product precipitated out on addition of cold pentane and was isolated by filtration. Five different acetylenes were successfully employed to prepare tris-triazoles TT-1-TT-5. The highest yield was obtained with phenylacetylene (Table S2, entry 1) and compound 2 afforded the best results.<smiles>[R]C#CC#N</smiles><smiles>Cc1cn(CC(C)(Cn2cc(-c3ccccc3)nn2)Cn2cc(-c3ccccc3)nn2)nn1</smiles>
TT-1 (99\%)

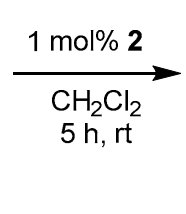<smiles>[R]c1cn(CC(C)(Cn2cc([R])nn2)Cn2cc([R])nn2)nn1</smiles><smiles>CC(C)(O)c1cn(CC(Cn2cc(C(C)(C)O)nn2)(Cn2cc(C(C)(C)O)nn2)Cn2cc(C(C)(C)O)nn2)nn1</smiles>

TT-2 (74\%)<smiles>CC(Cn1cc(CCO)nn1)(Cn1cc(CCO)nn1)Cn1cc(CCO)nn1</smiles>

$\mathrm{TT}-3(65 \%)$

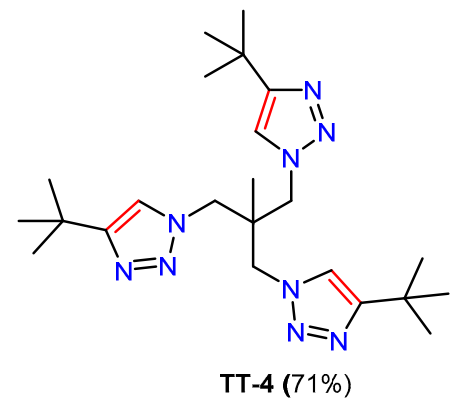<smiles>CCCc1cn(CC(C)(Cn2cc(CCC)nn2)Cn2cc(CCC)nn2)nn1</smiles>

Scheme 3. Synthesis of tris-triazoles TT-1-TT-5 via the [3+2] cycloaddition of a tris-azide with alkynes catalyzed by 2 .

\section{Materials and Methods}

Unless stated otherwise, all syntheses and manipulations were carried out under an inert atmosphere of dry argon or nitrogen gas using Schlenk line techniques or a glove box. All solvents were dried over appropriate drying agents, distilled, and stored over $3 \AA$ molecular sieves. ${ }^{1} \mathrm{H}$ and ${ }^{13} \mathrm{C}$ NMR spectra were recorded on a Bruker Avance III 300 or a Bruker Avance I 500 spectrometer (Bruker Corporation, Billerica, MA, USA) using the residual solvent peak as reference [95]: $\delta_{\mathrm{H}}\left[\mathrm{C}_{6} \mathrm{D}_{6}\right.$ 7.16, $\mathrm{CDCl}_{3} 7.26$ (Deutero GmbH, Kastellaun, Germany); $\mathrm{CD}_{2} \mathrm{Cl}_{2} 5.35$ (Carl Roth $\mathrm{GmbH}+\mathrm{Co}$. KG, Karlsruhe, Germany); THF- $d_{8} 3.58,1.73$ (Sigma-Aldrich, St. Louis, MO, USA)] ppm and $\delta_{\mathrm{C}}\left[\mathrm{C}_{6} \mathrm{D}_{6}\right.$ 
128.06, $\left.\mathrm{CDCl}_{3} 77.16, \mathrm{CD}_{2} \mathrm{Cl}_{2} 53.84, \mathrm{THF}-d_{8} 61.50,126.28\right] \mathrm{ppm}$ at $298 \mathrm{~K}$. EI-mass spectra were recorded with a Finnigan MAT $95(70 \mathrm{eV})$ (Thermo Finnigan MAT GmbH, Bremen, Germany ). Organic azides were prepared by literature methods [43]. All alkynes were purchased from commercial suppliers (Sigma-Aldrich, St. Louis, MO, USA or Acros Organics, Thermo Fisher Scientific, Geel, Belgium) and used without further purification. Compounds (IPrPh)I (1) and $\mathrm{Cu}\left(\mathrm{aIPr}^{\mathrm{Ph}}\right) \mathrm{I}(\mathbf{2})$ were synthesized according to the reported procedure [45].

\subsection{Synthesis of Complexes $\mathbf{3}$ and $\mathbf{4}$}

[Cu(aIPr $\left.{ }^{\mathrm{Ph}}\right)$ (IPr)]I (3): To a $100 \mathrm{~mL}$ Schlenk flask equipped with $\mathrm{Cu}\left(\mathrm{aIPr}^{\mathrm{Ph}}\right) \mathrm{I}(\mathbf{2})(1.0 \mathrm{~g}, 1.53 \mathrm{mmol})$ and $\operatorname{IPr}(594 \mathrm{mg}, 1.53 \mathrm{mmol})$ was added $20 \mathrm{~mL}$ of toluene. The reaction mixture was stirred overnight at room temperature. Filtration through a plug of Celite ${ }^{\circledR}$ (Carl Roth GmbH + Co., KG, Karlsruhe, Germany) afforded a clear solution. The volatiles were removed under vacuum to obtain the desired compound 3 as a colorless solid (1.29 g, 81\%). Elemental analysis (\%) calcd. for $3, \mathrm{C}_{60} \mathrm{H}_{76} \mathrm{~N}_{4} \mathrm{CuI}(1043)$ : C, 69.05; H, 7.34; N, 5.37; found: C, 69.35; H, 7.08; N, 5.02. ${ }^{1} \mathrm{H}-\mathrm{NMR}\left(300 \mathrm{MHz}, 298 \mathrm{~K}, \mathrm{THF}-d_{8}\right): \delta 0.69$ (d, $\left.J=6.79 \mathrm{~Hz}, 6 \mathrm{H}, \mathrm{CHMe}_{2}\right) ; 0.86\left(\mathrm{~d}, J=6.86 \mathrm{~Hz}, 6 \mathrm{H}, \mathrm{CHMe}_{2}\right) ; 1.00\left(\mathrm{~d}, J=6.85 \mathrm{~Hz}, 6 \mathrm{H}, \mathrm{CHMe}_{2}\right) ; 1.13(\mathrm{t}, J=$ $\left.6.65 \mathrm{~Hz}, 18 \mathrm{H}, \mathrm{CHMe}_{2}\right) ; 1.20\left(\mathrm{~d}, 12 \mathrm{H}, J=6.85 \mathrm{~Hz}, \mathrm{CHMe}_{2}\right) ; 2.24\left(\mathrm{~m}, 2 \mathrm{H}, \mathrm{CHMe}_{2}\right) ; 2.36\left(\mathrm{~m}, 2 \mathrm{H}, \mathrm{CHMe}_{2}\right)$; 2.62 (sept, $\left.J=6.85 \mathrm{~Hz}, 4 \mathrm{H}, \mathrm{CHMe}_{2}\right) ; 6.55\left(\mathrm{~s}, 1 \mathrm{H}, \mathrm{HNC}_{(\mathrm{aIPrPh})} \mathrm{C}\right) ; 6.84\left(\mathrm{~d}, J=7.38 \mathrm{~Hz}, 2 \mathrm{H}, o-\mathrm{C}_{6} \mathrm{H}_{5}\right)$; 7.11-7.16 (m, 4H, $\left.p-\mathrm{C}_{6} \mathrm{H}_{3}\right), 7.19-7.40\left(\mathrm{~m}, 8 \mathrm{H}, m-\mathrm{C}_{6} \mathrm{H}_{3}\right), 7.45-7.55\left(\mathrm{~m}, 3 \mathrm{H}, m-\mathrm{C}_{6} \mathrm{H}_{5}, p-\mathrm{C}_{6} \mathrm{H}_{5}\right) ; 7.78(\mathrm{~s}, 2 \mathrm{H}$, NCHCHN) ppm. ${ }^{13} \mathrm{C}\left\{{ }^{1} \mathrm{H}\right\}-\mathrm{NMR}\left(75 \mathrm{MHz}, 25{ }^{\circ} \mathrm{C}\right.$, THF- $\left.d_{8}\right): \delta 22.81\left(\mathrm{CHMe}_{2}\right) ; 22.94\left(\mathrm{CHMe}_{2}\right) ; 24.48$ $\left(\mathrm{CHMe}_{2}\right) ; 25.34\left(\mathrm{CHMe}_{2}, \mathrm{CHMe}_{2}\right) ; 26.29\left(\mathrm{CHMe}_{2}\right) ; 29.73\left(\mathrm{CHMe}_{2}\right) ; 29.83\left(\mathrm{CHMe}_{2}\right) ; 30.05\left(\mathrm{CHMe}_{2}\right)$; $123.67\left(o-\mathrm{C}_{6} \mathrm{H}_{3}\right) ; 125.20\left(p-\mathrm{C}_{6} \mathrm{H}_{3}\right) ; 125.58\left(p-\mathrm{C}_{6} \mathrm{H}_{3}\right) ; 126.05\left(m-\mathrm{C}_{6} \mathrm{H}_{3}\right) ; 126.08(\mathrm{NCH}) ; 129.76\left(p-\mathrm{C}_{6} \mathrm{H}_{3}\right)$; $129.98\left(o-\mathrm{C}_{6} \mathrm{H}_{5}\right) ; 131.47,131.81\left(m-\mathrm{C}_{6} \mathrm{H}_{5}, p-\mathrm{C}_{6} \mathrm{H}_{5}\right) ; 132.09(\mathrm{NCH}) ; 132.48,132.57,136.02\left(o-\mathrm{C}_{6} \mathrm{H}_{3}\right)$; 136.44, $145.17\left(o-\mathrm{C}_{6} \mathrm{H}_{3}\right) ; 145.80,145.89,146.58\left(\right.$ ipso $\left.^{-\mathrm{C}_{6}} \mathrm{H}_{5}\right) ; 159.53\left(\mathrm{C}_{(\mathrm{aIPrPh})}-\mathrm{Cu}\right) ; 180.99\left(\mathrm{C}_{(\mathrm{IPr})}-\mathrm{Cu}\right) \mathrm{ppm}$. ESI-MS $m / z$ [\%]: $915.5[\{\mathrm{M}-\mathrm{I}\}]^{+}$.

Synthesis of [Cu(aIPr $\left.\left.{ }^{\mathrm{Ph}}\right)_{2}\right] \mathrm{I}$ (4): To a $100 \mathrm{~mL}$ Schlenk flask equipped with (IPrPh)I (1) (1.0 g, $1.69 \mathrm{mmol}), \mathrm{KN}\left(\mathrm{SiMe}_{3}\right)_{2}(337 \mathrm{mg}, 1.69 \mathrm{mmol})$, and $\mathrm{CuI}(161 \mathrm{mg}, 0.84 \mathrm{mmol})$ was added $30 \mathrm{~mL}$ of pre-cooled THF at $0{ }^{\circ} \mathrm{C}$. The reaction mixture was brought to room temperature and further stirred overnight. Filtration through a plug of Celite ${ }^{\circledR}$ afforded a clear solution. The volatiles were removed under vacuum to obtain an off-white solid, which was washed with $20 \mathrm{~mL}$ of $n$-pentane and dried to yield compound $4(0.75 \mathrm{~g}, 40 \%)$. Elemental analysis (\%) calcd for $4, \mathrm{C}_{66} \mathrm{H}_{80} \mathrm{~N}_{4} \mathrm{CuI}$ (1119): C, 70.79; $\mathrm{H}$, 7.20; N, 5.00; found: C, 71.21; H, 7.11; N, 4.72. ${ }^{1} \mathrm{H}-\mathrm{NMR}\left(500 \mathrm{MHz}, 298 \mathrm{~K}, \mathrm{THF}-d_{8}\right): \delta 1.01(\mathrm{t}, J=6.9 \mathrm{~Hz}$, $\left.24 \mathrm{H}, \mathrm{HCMe}_{2}\right) ; 1.12\left(\mathrm{~d}, J=6.8 \mathrm{~Hz}, 12 \mathrm{H}, \mathrm{HCMe}_{2}\right) ; 1.22\left(\mathrm{~d}, J=6.8 \mathrm{~Hz}, 12 \mathrm{H}, \mathrm{HCMe}_{2}\right) ; 2.47-2.61(\mathrm{~m}$, $\left.8 \mathrm{H}, \mathrm{CHMe}_{2}\right) ; 6.91\left(\mathrm{~d}, J=7.4 \mathrm{~Hz}, 4 \mathrm{H}, o-\mathrm{C}_{6} \mathrm{H}_{3}\right) ; 7.08(\mathrm{~s}, 2 \mathrm{H}, \mathrm{NCH}) ; 7.18\left(\mathrm{t}, J=7.5 \mathrm{~Hz}, 4 \mathrm{H}, m-\mathrm{C}_{6} \mathrm{H}_{5}\right)$; $7.23\left(\mathrm{~d}, J=7.8 \mathrm{~Hz}, 4 \mathrm{H}, m-\mathrm{C}_{6} \mathrm{H}_{3}\right) ; 7.30\left(\mathrm{t}, J=7.5 \mathrm{~Hz}, 2 \mathrm{H}, p-\mathrm{C}_{6} \mathrm{H}_{3}\right) ; 7.38\left(\mathrm{~m}, 6 \mathrm{H}, m-\mathrm{C}_{6} \mathrm{H}_{3}, p-\mathrm{C}_{6} \mathrm{H}_{5}\right) ; 7.54$ $\left(\mathrm{t}, J=7.8 \mathrm{~Hz}, 2 \mathrm{H}, p-\mathrm{C}_{6} \mathrm{H}_{3}\right)$ ppm. ${ }^{13} \mathrm{C}\left\{{ }^{1} \mathrm{H}\right\}-\mathrm{NMR}\left(125.76 \mathrm{MHz}, 25{ }^{\circ} \mathrm{C}, \mathrm{THF}-d_{8}\right): \delta 22.89\left(\mathrm{CHMe}_{2}\right) ; 22.95$ $\left(\mathrm{CHMe}_{2}\right) ; 25.90\left(\mathrm{CHMe}_{2}\right) ; 26.38\left(\mathrm{CHMe}_{2}\right) ; 29.91\left(\mathrm{CHMe}_{2}\right) ; 30.08\left(\mathrm{CHMe}_{2}\right) ; 124.07,125.55,125.95,129.68$ $\left(m-\mathrm{C}_{6} \mathrm{H}_{5}\right) ; 130.10\left(o-\mathrm{C}_{6} \mathrm{H}_{5}\right) ; 131.51\left(p-\mathrm{C}_{6} \mathrm{H}_{5}\right) ; 131.73(\mathrm{NCH}) ; 132.18\left(p-\mathrm{C}_{6} \mathrm{H}_{3}\right) ; 132.33\left(p-\mathrm{C}_{6} \mathrm{H}_{3}\right) ; 132.43$ $\left(o-\mathrm{C}_{6} \mathrm{H}_{3}\right) ; 136.65\left(o-\mathrm{C}_{6} \mathrm{H}_{3}\right) ; 145.84\left(\right.$ ipso- $\left.\mathrm{C}_{6} \mathrm{H}_{5}\right) ; 146.01$ (ipso- $\left.\mathrm{C}_{6} \mathrm{H}_{5}\right) ; 161.05(\mathrm{C}-\mathrm{Cu}) \mathrm{ppm}$. ESI-MS m/z [\%]: $991.6[\{\mathrm{M}-\mathrm{I}\}]^{+}$.

\subsection{Crystal Structure Determinations}

The data of structures 3, 4 (Table S3), TZ-2, and TZ-4 (Table S4) were collected at $100 \mathrm{~K}$ on a Bruker D8 three circle diffractometer equipped with a microfocus source [96] and for structure TZ-3 (Table S4) on a Bruker D8 TXS-Mo-rotating anode. All data were integrated with SAINT [97]. A multi-scan absorption correction for all structures and a $3 \lambda$ correction [98] for structures $\mathbf{3}, \mathbf{4}, \mathbf{T Z}-\mathbf{2}$, and TZ-4 were applied using SADABS [99]. The structures were solved by SHELXT [100] and refined on $F^{2}$ using SHELXL [101] in the graphical user interface ShelXle [102]. 


\subsection{General Procedure for Catalysis}

Method A. A reaction vessel was charged with the azide ( $1 \mathrm{mmol})$, alkyne $(1.1 \mathrm{mmol})$, and the appropriate catalyst and stirred without any added solvent (neat) at $\mathrm{rt}\left(25^{\circ} \mathrm{C}\right)$ for the appropriate period. The conversion was monitored by the ${ }^{1} \mathrm{H}$ NMR spectroscopic analysis.

Method B. To a reaction vessel containing the azide $(1 \mathrm{mmol})$, alkyne $(1.1 \mathrm{mmol})$, and the appropriate catalyst was added $5 \mathrm{~mL}$ dichloromethane and stirred at $\mathrm{rt}$ for the appropriate period. The conversion was monitored by the ${ }^{1} \mathrm{H}$ NMR spectroscopic analysis.

\section{Conclusions}

In conclusion, the synthesis and characterization of two new aNHC-copper complexes 3 and 4 featuring a 1,3-imidazol-4-ylidene type carbene(s) are reported. The catalytic activity of compounds 2, 3 , and $\mathbf{4}$ has been explored for the [3+2] cycloaddition reactions of alkynes with azides. Compound $\mathbf{2}$ has been found to be extremely reactive, leading to a high TON value of 2000 (entry 4 Table S1) and a TOF value of $2400 \mathrm{~h}^{-1}$ (entry 2, Table S1). These compounds are also very efficient for the "three-fold [3+2] cycloaddition" of tris-azides with alkynes, enabling very facile access to tris-triazole derivatives.

Supplementary Materials: The following are available online at www.mdpi.com/2073-4344/7/9/262/s1. Synthesis and characterization details of copper complexes 3 and 4 and catalysis products; ${ }^{1} \mathrm{H}$ and ${ }^{13} \mathrm{C}$ NMR spectra of complexes 3, 4, and triazoles, and tris-triazoles; experimental details of catalytic procedures; and details of single crystal X-ray diffraction studies are provided in the supporting information. Single crystal X-ray crystallographic data of 3, 4, TZ-2, TZ-3, and TZ-4 can also be obtained free of charge from the Cambridge Crystallographic Data Centre via www.ccdc.cam.ac.uk/data-request/cif, CCDC number: 1560171-1560175.

Acknowledgments: Support from the Deutsche Forschungsgemeinschaft (DFG) is gratefully acknowledged. We are thankful to Norbert W. Mitzel for his generous support and encouragement.

Author Contributions: Nga Kim T. Ho, Sven O. Reichmann, Dennis Rottschäfer, Regine Herbst-Irmer, and Rajendra S. Ghadwal conceived and designed experiments, collected and analyzed the data, and wrote the manuscript.

Conflicts of Interest: The authors declare no conflict of interest.

\section{References}

1. Hopkinson, M.N.; Richter, C.; Schedler, M.; Glorius, F. An overview of N-heterocyclic carbenes. Nature 2014, 510, 485-496. [CrossRef] [PubMed]

2. Diez-Gonzalez, S.; Marion, N.; Nolan, S.P. N-Heterocyclic carbenes in late transition metal catalysis. Chem. Rev. 2009, 109, 3612-3676. [CrossRef] [PubMed]

3. Glorius, F. N-Heterocyclic Carbenes in Transition Metal Catalysis; Springer: Berlin/Heidelberg, Germany, 2007; Volume 21.

4. Herrmann, W.A. N-Heterocyclic Carbenes: A new concept in organometallic catalysis. Angew. Chem. Int. Ed. 2002, 41, 1290-1309. [CrossRef]

5. Nolan, S.P. N-Heterocyclic Carbenes in Synthesis; Wiley-VCH Verlag GmbH \& Co., KGaA: Weinheim, Germany, 2006.

6. Nolan, S.P. N-Heterocyclic Carbenes: Effective Tools for Organometallic Synthesis; Wiley-VCH Verlag GmbH \& Co., KGaA: Weinheim, Germany, 2014.

7. Lazreg, F.; Nahra, F.; Cazin, C.S.J. Copper-NHC complexes in catalysis. Coord. Chem. Rev. 2015, 293, 48-79. [CrossRef]

8. Enders, D.; Balensiefer, T. Nucleophilic Carbenes in Asymmetric Organocatalysis. Acc. Chem. Res. 2004, 37 , 534-541. [CrossRef] [PubMed]

9. Cesar, V.; Bellemin-Laponnaz, S.; Gade, L.H. Chiral N-heterocyclic carbenes as stereodirecting ligands in asymmetric catalysis. Chem. Soc. Rev. 2004, 33, 619-636. [CrossRef] [PubMed]

10. Boeda, F.; Nolan, S.P. N-Heterocyclic carbene-containing complexes in catalysis. Annu. Rep. Prog. Chem. Sect. B Org. Chem. 2008, 104, 184-210. [CrossRef]

11. Fortman, G.C.; Nolan, S.P. N-Heterocyclic carbene (NHC) ligands and palladium in homogeneous cross-coupling catalysis: A perfect union. Chem. Soc. Rev. 2011, 40, 5151-5169. [CrossRef] [PubMed] 
12. Bantreil, X.; Nolan, S.P. Synthesis of N-heterocyclic carbene ligands and derived ruthenium olefin metathesis catalysts. Nat. Protoc. 2011, 6, 69-77. [CrossRef] [PubMed]

13. Grossmann, A.; Enders, D. N-Heterocyclic carbene catalyzed domino reactions. Angew. Chem. Int. Ed. 2012, 51, 314-325. [CrossRef] [PubMed]

14. Soleilhavoup, M.; Bertrand, G. Cyclic (alkyl)(amino)carbenes (CAACs): Stable carbenes on the rise. Acc. Chem. Res. 2015, 48, 256-266. [CrossRef] [PubMed]

15. Wang, Y.; Robinson, G.H. N-heterocyclic carbene-main-group chemistry: A rapidly evolving field. Inorg. Chem. 2014, 53, 11815-11832. [CrossRef] [PubMed]

16. Martin, C.D.; Soleilhavoup, M.; Bertrand, G. Carbene-stabilized main group radicals and radical ions. Chem. Sci. 2013, 4, 3020-3030. [CrossRef] [PubMed]

17. Ghadwal, R.S.; Azhakar, R.; Roesky, H.W. Dichlorosilylene: A high temperature transient species to an indispensable building block. Acc. Chem. Res. 2013, 46, 444-456. [CrossRef] [PubMed]

18. Bidal, Y.D.; Santoro, O.; Melaimi, M.; Cordes, D.B.; Slawin, A.M.Z.; Bertrand, G.; Cazin, C.S.J. Generalization of the copper to late-transition-metal transmetallation to carbenes beyond N-heterocyclic carbenes. Chem. Eur. J. 2016, 22, 9404-9409. [CrossRef] [PubMed]

19. Ghadwal, R.S. Carbon-based two electron sigma-donor ligands beyond classical N-heterocyclic carbenes. Dalton Trans. 2016, 45, 16081-16095. [CrossRef] [PubMed]

20. Lepetit, C.; Maraval, V.; Canac, Y.; Chauvin, R. On the nature of the dative bond: Coordination to metals and beyond. The carbon case. Coord. Chem. Rev. 2016, 308, 59-75. [CrossRef]

21. Melaimi, M.; Soleilhavoup, M.; Bertrand, G. Stable cyclic carbenes and related species beyond diaminocarbenes. Angew. Chem. Int. Ed. 2010, 49, 8810-8849. [CrossRef] [PubMed]

22. Schuster, O.; Yang, L.; Raubenheimer, H.G.; Albrecht, M. Beyond conventional N-heterocyclic carbenes: Abnormal, remote and other classes of NHC ligands with reduced heteroatom stabilization. Chem. Rev. 2009, 109, 3445-3478. [CrossRef] [PubMed]

23. Ghadwal, R.S.; Rottschäfer, D.; Blomeyer, S.; Neumann, B.; Stammler, H.-G. Silylene-functionalized N-heterocyclic carbene (Si-NHC). Chem. Eur. J. 2017. [CrossRef] [PubMed]

24. Schnee, G.; Nieto Faza, O.; Specklin, D.; Jacques, B.; Karmazin, L.; Welter, R.; Silva López, C.; Dagorne, S. Normal-to-abnormal NHC rearrangement of AlIII, GaIII, and InIII trialkyl complexes: Scope, mechanism, reactivity studies, and $\mathrm{H} 2$ activation. Chem. Eur. J. 2015, 21, 17959-17972. [CrossRef] [PubMed]

25. Poulain, A.; Iglesias, M.; Albrecht, M. Abnormal NHC palladium complexes: Synthesis, structure, and reactivity. Curr. Org. Chem. 2011, 15, 3325-3336. [CrossRef]

26. Xu, X.; Xu, B.; Li, Y.; Hong, S.H. Abnormal N-heterocyclic carbene promoted Suzuki-Miyaura coupling reaction: A comparative study. Organometallics 2010, 29, 6343-6349. [CrossRef]

27. Aldeco-Perez, E.; Rosenthal, A.J.; Donnadieu, B.; Parameswaran, P.; Frenking, G.; Bertrand, G. Isolation of a C5-deprotonated imidazolium, a crystalline "Abnormal" N-heterocyclic carbene. Science 2009, 326, 556-559. [CrossRef] [PubMed]

28. Crittall, M.R.; Ellul, C.E.; Mahon, M.F.; Saker, O.; Whittlesey, M.K. Abnormal coordination of Arduengo's carbene upon reaction with M3 (CO) 12 (M = Ru, Os). Dalton Trans. 2008, 4209-4211. [CrossRef] [PubMed]

29. Cooke, C.E.; Jennings, M.C.; Pomeroy, R.K.; Clyburne, J.A.C. Normal and abnormal NHC coordination in [Os4( $\mu-\mathrm{H}) 4(\mathrm{CO}) 11(\mathrm{IMes})]$ and exhaustive dehydrogenation of an IMes methyl group. Organometallics 2007, 26, 6059-6062. [CrossRef]

30. Arnold, P.L.; Pearson, S. Abnormal N-heterocyclic carbenes. Coord. Chem. Rev. 2007, 251, 596-609. [CrossRef]

31. Chianese, A.R.; Kovacevic, A.; Zeglis, B.M.; Faller, J.W.; Crabtree, R.H. Abnormal C5-bound N-heterocyclic carbenes: Extremely strong electron donor ligands and their iridium(I) and iridium(III) complexes. Organometallics 2004, 23, 2461-2468. [CrossRef]

32. Grundemann, S.; Kovacevic, A.; Albrecht, M.; Faller, J.W.; Crabtree, R.H. Abnormal binding in a carbene complex formed from an imidazolium salt and a metal hydride complex. Chem. Commun. 2001, 2274-2275. [CrossRef]

33. Droge, T.; Glorius, F. The measure of all rings-N-heterocyclic carbenes. Angew. Chem. Int. Ed. 2010, 49, 6940-6952. [CrossRef] [PubMed]

34. Nelson, D.J.; Nolan, S.P. Quantifying and understanding the electronic properties of N-heterocyclic carbenes. Chem. Soc. Rev. 2013, 42, 6723-6753. [CrossRef] [PubMed] 
35. Guisado-Barrios, G.; Bouffard, J.; Donnadieu, B.; Bertrand, G. Crystalline 1H-1,2,3-triazol-5-ylidenes: New stable mesoionic carbenes (MICs). Angew. Chem. Int. Ed. 2010, 49, 4759-4762. [CrossRef] [PubMed]

36. Crabtree, R.H. Abnormal, mesoionic and remote N-heterocyclic carbene complexes. Coord. Chem. Rev. 2013, 257, 755-766. [CrossRef]

37. Heckenroth, M.; Kluser, E.; Neels, A.; Albrecht, M. Neutral ligands with exceptional donor ability for palladium-catalyzed alkene hydrogenation. Angew. Chem. Int. Ed. 2007, 46, 6293-6296. [CrossRef] [PubMed]

38. Albrecht, M. C4-bound imidazolylidenes: From curiosities to high-impact carbene ligands. Chem. Commun. 2008, 3601-3610. [CrossRef] [PubMed]

39. Martin, D.; Melaimi, M.; Soleilhavoup, M.; Bertrand, G. A brief survey of our contribution to stable carbene chemistry. Organometallics 2011, 30, 5304-5313. [CrossRef] [PubMed]

40. Prades, A.; Viciano, M.; Sanau, M.; Peris, E. Preparation of a series of "Ru(p-cymene)" complexes with different $N$-heterocyclic carbene ligands for the catalytic $\beta$-alkylation of secondary alcohols and dimerization of phenylacetylene. Organometallics 2008, 27, 4254-4259. [CrossRef]

41. Saha, S.; Ghatak, T.; Saha, B.; Doucet, H.; Bera, J.K. Steric control at the wingtip of a bis-N-heterocyclic carbene ligand: Coordination behavior and catalytic responses of its ruthenium compounds. Organometallics 2012, 31, 5500-5505. [CrossRef]

42. Keitz, B.K.; Bouffard, J.; Bertrand, G.; Grubbs, R.H. Protonolysis of a ruthenium-carbene bond and applications in olefin metathesis. J. Am. Chem. Soc. 2011, 133, 8498-8501. [CrossRef] [PubMed]

43. Bidal, Y.D.; Lesieur, M.; Melaimi, M.; Nahra, F.; Cordes, D.B.; Athukorala Arachchige, K.S.; Slawin, A.M.Z.; Bertrand, G.; Cazin, C.S.J. Copper(I) complexes bearing carbenes beyond classical N-heterocyclic carbenes: Synthesis and catalytic activity in "Click chemistry". Adv. Synth. Catal. 2015, 357, 3155-3161. [CrossRef]

44. Sau, S.C.; Roy, S.R.; Sen, T.K.; Mullangi, D.; Mandal, S.K. An abnormal N-heterocyclic carbene-copper(I) complex in click chemistry. Adv. Synth. Catal. 2013, 355, 2982-2991. [CrossRef]

45. Ghadwal, R.S.; Reichmann, S.O.; Herbst-Irmer, R. Palladium-catalyzed direct C2-arylation of an N-heterocyclic carbene: An atom-economic route to mesoionic carbene ligands. Chem. Eur. J. 2015, 21, 4247-4251. [CrossRef] [PubMed]

46. Ghadwal, R.S.; Ho, N.K.; Neumann, B.; Stammler, G.; Menezes da Silva, V.H.; Watanabe, D.; Braga, A.A.C. Nickel-catalysed direct C2-arylation of N-heterocyclic carbene. Dalton Trans. 2017. [CrossRef]

47. Rottschäfer, D.; Schürmann, C.J.; Lamm, J.-H.; Paesch, A.N.; Neumann, B.; Ghadwal, R.S. Abnormal-NHC palladium(II) complexes: Rational synthesis, structural elucidation, and catalytic activity. Organometallics 2016, 35, 3421-3429. [CrossRef]

48. Ghadwal, R.S.; Rottschäfer, D.; Schürmann, C.J. Expedient access to normal- and abnormal- N-heterocyclic carbene (NHC) magnesium compounds from imidazolium salts. Z. Anorg. Allg. Chem. 2016, 642, 1236-1240. [CrossRef]

49. Ghadwal, R.S.; Lamm, J.-H.; Rottschafer, D.; Schurmann, C.J.; Demeshko, S. Facile routes to abnormal-NHC-cobalt(II) complexes. Dalton Trans. 2017, 46, 7664-7667. [CrossRef] [PubMed]

50. Meldal, M.; Tornøe, C.W. Cu-catalyzed azide-alkyne cycloaddition. Chem. Rev. 2008, 108, $2952-3015$. [CrossRef] [PubMed]

51. Finn, M.G.; Fokin, V.V. Click chemistry: Function follows form. Chem. Soc. Rev. 2010, 39, 1231-1232. [CrossRef] [PubMed]

52. Berg, R.; Straub, B.F. Advancements in the mechanistic understanding of the copper-catalyzed azide-alkyne cycloaddition. Beilstein J. Org. Chem. 2013, 9, 2715-2750. [CrossRef] [PubMed]

53. Himo, F.; Lovell, T.; Hilgraf, R.; Rostovtsev, V.V.; Noodleman, L.; Sharpless, K.B.; Fokin, V.V. Copper(I)-catalyzed synthesis of azoles. DFT study predicts unprecedented reactivity and intermediates. J. Am. Chem. Soc. 2005, 127, 210-216. [CrossRef] [PubMed]

54. Kolb, H.C.; Finn, M.G.; Sharpless, K.B. Click chemistry: Diverse chemical function from a few good reactions. Angew. Chem. Int. Ed. 2001, 40, 2004-2021. [CrossRef]

55. Schulze, B.; Schubert, U.S. Beyond click chemistry-Supramolecular interactions of 1,2,3-triazoles. Chem. Soc. Rev. 2014, 43, 2522-2571. [CrossRef] [PubMed]

56. Straub, B.; Holm, S.; Siegle, A.; Loos, C.; Rominger, F. Preparation and N-alkylation of 4-aryl-1,2,4-triazoles. Synthesis 2010, 2010, 2278-2286. [CrossRef]

57. Wang, C.; Wang, D.; Yu, S.; Cornilleau, T.; Ruiz, J.; Salmon, L.; Astruc, D. Design and applications of an efficient amphiphilic "Click" CuI catalyst in water. ACS Catal. 2016, 6, 5424-5431. [CrossRef] 
58. Wang, D.; Deraedt, C.; Salmon, L.; Labrugère, C.; Etienne, L.; Ruiz, J.; Astruc, D. A tris(triazolate) ligand for a highly active and magneticall recoverable palladium catalyst of selective alcohol oxidation using air at atmospheric pressure. Chem. Eur. J. 2015, 21, 6501-6510. [CrossRef] [PubMed]

59. He, C.; Shreeve, J.N.M. Energetic materials with promising properties: Synthesis and characterization of 4,4'-bis(5-nitro-1,2,3-2H-triazole) derivatives. Angew. Chem. Int. Ed. 2015, 54, 6260-6264. [CrossRef] [PubMed]

60. Dippold, A.A.; Klapötke, T.M. A study of dinitro-bis-1,2,4-triazole-1,1'-diol and derivatives: Design of high-performance insensitive energetic materials by the introduction of N-oxides. J. Am. Chem. Soc. 2013, 135, 9931-9938. [CrossRef] [PubMed]

61. Brantley, J.N.; Wiggins, K.M.; Bielawski, C.W. Unclicking the click: Mechanically facilitated 1,3-dipolar cycloreversions. Science 2011, 333, 1606-1609. [CrossRef] [PubMed]

62. Juricek, M.; Kouwer, P.H.J.; Rowan, A.E. Triazole: A unique building block for the construction of functional materials. Chem. Commun. 2011, 47, 8740-8749. [CrossRef] [PubMed]

63. Diez-Gonzalez, S.; Escudero-Adan, E.C.; Benet-Buchholz, J.; Stevens, E.D.; Slawin, A.M.Z.; Nolan, S.P. [(NHC)CuX] complexes: Synthesis, characterization and catalytic activities in reduction reactions and click chemistry. On the advantage of using well-defined catalytic systems. Dalton Trans. 2010, 39, 7595-7606. [CrossRef] [PubMed]

64. Makarem, A.; Berg, R.; Rominger, F.; Straub, B.F. A fluxional copper acetylide cluster in CuAAC catalysis. Angew. Chem. Int. Ed. 2015, 54, 7431-7435. [CrossRef] [PubMed]

65. Diez-Gonzalez, S.; Nolan, S.P. [(NHC)2Cu]X Complexes as efficient catalysts for azide-alkyne click chemistry at low catalyst loadings. Angew. Chem. Int. Ed. 2008, 47, 8881-8884. [CrossRef] [PubMed]

66. Diaz Velazquez, H.; Ruiz Garcia, Y.; Vandichel, M.; Madder, A.; Verpoort, F. Water-soluble NHC-Cu catalysts: Applications in click chemistry, bioconjugation and mechanistic analysis. Org. Biomol. Chem. 2014, 12, 9350-9356. [CrossRef] [PubMed]

67. Hohloch, S.; Sarkar, B.; Nauton, L.; Cisnetti, F.; Gautier, A. Are Cu(I)-mesoionic NHC carbenes associated with nitrogen additives the best $\mathrm{Cu}$-carbene catalysts for the azide-alkyne click reaction in solution? A case study. Tetrahedron Lett. 2013, 54, 1808-1812. [CrossRef]

68. Nakamura, T.; Terashima, T.; Ogata, K.; Fukuzawa, S. Copper(I) 1,2,3-triazol-5-ylidene complexes as efficient catalysts for click reactions of azides with alkynes. Org. Lett. 2011, 13, 620-623. [CrossRef] [PubMed]

69. Diez-Gonzalez, S.; Stevens, E.D.; Nolan, S.P. A [(NHC)CuCl] complex as a latent click catalyst. Chem. Commun. 2008, 4747-4749. [CrossRef] [PubMed]

70. Diez-Gonzalez, S.; Nolan, S.P. N-heterocyclic carbene-copper(I) complexes in homogeneous catalysis. Synlett 2007, 2007, 2158-2167. [CrossRef]

71. Diez-Gonzalez, S.; Correa, A.; Cavallo, L.; Nolan, S.P. (NHC)copper(I)-catalyzed [3+2] cycloaddition of azides and mono- or disubstituted alkynes. Chem. Eur. J. 2006, 12, 7558-7564. [CrossRef] [PubMed]

72. Bidal, Y.D.; Lesieur, M.; Melaimi, M.; Cordes, D.B.; Slawin, A.M.; Bertrand, G.; Cazin, C.S. A simple access to transition metal cyclopropenylidene complexes. Chem. Commun. 2015, 51, 4778-4781. [CrossRef] [PubMed]

73. Sau, S.C.; Roy, S.R.; Mandal, S.K. One-pot consecutive catalysis by integrating organometallic catalysis with organocatalysis. Chem. Asian. J. 2014, 9, 2806-2813. [CrossRef] [PubMed]

74. Roy, S.R.; Sau, S.C.; Mandal, S.K. Chemoselective reduction of the carbonyl functionality through hydrosilylation: Integrating click catalysis with hydrosilylation in one pot. J. Org. Chem. 2014, 79, 9150-9160. [CrossRef] [PubMed]

75. Hu, X.; Castro-Rodriguez, I.; Meyer, K. A bis-carbene alkenyl copper(I) complex from a tripodal tris-carbene ligand. Organometallics 2003, 22, 3016-3018. [CrossRef]

76. Filonenko, G.A.; Cosimi, E.; Lefort, L.; Conley, M.P.; Coperet, C.; Lutz, M.; Hensen, E.J.M.; Pidko, E.A. Lutidine-derived Ru-CNC hydrogenation pincer catalysts with versatile coordination properties. ACS Catal. 2014, 4, 2667-2671. [CrossRef]

77. Bitzer, M.J.; Pothig, A.; Jandl, C.; Kühn, F.E.; Baratta, W. Ru-Ag and Ru-Au dicarbene complexes from an abnormal carbene ruthenium system. Dalton Trans. 2015, 44, 11686-11689. [CrossRef] [PubMed]

78. Krueger, A.; Albrecht, M. Rhodium carbene complexes as versatile catalyst precursors for Si-H bond activation. Chem. Eur. J. 2012, 18, 652-658. [CrossRef] [PubMed] 
79. Kruger, A.; Haller, L.J.L.; Muller-Bunz, H.; Serada, O.; Neels, A.; Macgregor, S.A.; Albrecht, M. Smooth C(alkyl)-H bond activation in rhodium complexes comprising abnormal carbene ligands. Dalton Trans. 2011, 40, 9911-9920. [CrossRef] [PubMed]

80. Zuo, W.; Braunstein, P. N-Heterocyclic dicarbene iridium(III) pincer complexes featuring mixed $\mathrm{NHC} /$ abnormal NHC ligands and their applications in the transfer dehydrogenation of cyclooctane. Organometallics 2012, 31, 2606-2615. [CrossRef]

81. Tang, C.Y.; Smith, W.; Vidovic, D.; Thompson, A.L.; Chaplin, A.B.; Aldridge, S. Sterically encumbered Iridium bis(N-heterocyclic carbene) systems: Multiple C-H activation processes and isomeric normal/abnormal carbene complexes. Organometallics 2009, 28, 3059-3066. [CrossRef]

82. Tan, K.V.; Dutton, J.L.; Skelton, B.W.; Wilson, D.J.D.; Barnard, P.J. Nickel(II) and palladium(II) complexes with chelating N-heterocyclic carbene amidate ligands: Interplay between normal and abnormal coordination modes. Organometallics 2013, 32, 1913-1923. [CrossRef]

83. Lebel, H.; Janes, M.K.; Charette, A.B.; Nolan, S.P. Structure and reactivity of "unusual" N-heterocyclic carbene (NHC) palladium complexes synthesized from imidazolium salts. J. Am. Chem. Soc. 2004, 126, 5046-5047. [CrossRef] [PubMed]

84. Danopoulos, A.A.; Tsoureas, N.; Wright, J.A.; Light, M.E. N-Heterocyclic pincer dicarbene complexes of iron(II): C-2 and C-5 Metalated carbenes on the same metal center. Organometallics 2004, 23, 166-168. [CrossRef]

85. Varonka, M.S.; Warren, T.H. Three-coordinate N-heterocyclic carbene nickel nitrosyl complexes. Organometallics 2010, 29, 717-720. [CrossRef]

86. Santoro, O.; Lazreg, F.; Cordes, D.B.; Slawin, A.M.Z.; Cazin, C.S.J. Homoleptic and heteroleptic bis-NHC $\mathrm{Cu}(\mathrm{I})$ complexes as carbene transfer reagents. Dalton Trans. 2016, 45, 4970-4973. [CrossRef] [PubMed]

87. Lazreg, F.; Slawin, A.M.Z.; Cazin, C.S.J. Heteroleptic bis(N-heterocyclic carbene) Copper(I) complexes: Highly efficient systems for the [3+2] cycloaddition of azides and alkynes. Organometallics 2012, 31, 7969-7975. [CrossRef]

88. Weisser, F.; Stevens, H.; Klein, J.; van der Meer, M.; Hohloch, S.; Sarkar, B. Tailoring Ru(II) pyridine/triazole oxygenation catalysts and using photoreactivity to probe their electronic properties. Chem. Eur. J. 2015, 21, 8926-8938. [CrossRef] [PubMed]

89. Schweinfurth, D.; Sommer, M.G.; Atanasov, M.; Demeshko, S.; Hohloch, S.; Meyer, F.; Neese, F.; Sarkar, B. The ligand field of the azido ligand: Insights into bonding parameters and magnetic anisotropy in a $\mathrm{Co}(\mathrm{II})$-azido complex. J. Am. Chem. Soc. 2015, 137, 1993-2005. [CrossRef] [PubMed]

90. Maity, R.; van der Meer, M.; Hohloch, S.; Sarkar, B. Di- and trinuclear iridium(III) complexes with poly-mesoionic carbenes synthesized through selective base-dependent metalation. Organometallics 2015, 34, 3090-3096. [CrossRef]

91. Maity, R.; van der Meer, M.; Sarkar, B. Redox-active multinuclear Pd(II) complexes with bis- and tris-mesoionic carbenes. Dalton Trans. 2015, 44, 46-49. [CrossRef] [PubMed]

92. Etayo, P.; Ayats, C.; Pericas, M.A. Synthesis and catalytic applications of C3-symmetric tris(triazolyl)methanol ligands and derivatives. Chem. Commun. 2016, 52, 1997-2010. [CrossRef] [PubMed]

93. Chan, T.R.; Hilgraf, R.; Sharpless, K.B.; Fokin, V.V. Polytriazoles as copper(I)-stabilizing ligands in catalysis. Org. Lett. 2004, 6, 2853-2855. [CrossRef] [PubMed]

94. Hein, J.E.; Fokin, V.V. Copper-catalyzed azide-alkyne cycloaddition (CuAAC) and beyond: New reactivity of copper(I) acetylides. Chem. Soc. Rev. 2010, 39, 1302-1315. [CrossRef] [PubMed]

95. Fulmer, G.R.; Miller, A.J.M.; Sherden, N.H.; Gottlieb, H.E.; Nudelman, A.; Stoltz, B.M.; Bercaw, J.E.; Goldberg, K.I. NMR chemical shifts of trace impurities: Common laboratory solvents, organics, and gases in deuterated solvents relevant to the organometallic chemist. Organometallics 2010, 29, 2176-2179. [CrossRef]

96. Schulz, T.; Meindl, K.; Leusser, D.; Stern, D.; Graf, J.; Michaelsen, C.; Ruf, M.; Sheldrick, G.M.; Stalke, D. A comparison of a microfocus $\mathrm{X}$-ray source and a conventional sealed tube for crystal structure determination. J. Appl. Cryst. 2009, 42, 885-891. [CrossRef]

97. Bruker AXS Inc. In Bruker Apex CCD, SAINT v8.30C; Bruker AXS Inst. Inc.: Madison, WI, USA, 2013.

98. Krause, L.; Herbst-Irmer, R.; Stalke, D. An empirical correction for the influence of low-energy contamination. J. Appl. Cryst. 2015, 48, 1907-1913. [CrossRef]

99. Krause, L.; Herbst-Irmer, R.; Sheldrick, G.M.; Stalke, D. Comparison of silver and molybdenum microfocus X-ray sources for single-crystal structure determination. J. Appl. Cryst. 2015, 48, 3-10. [CrossRef] [PubMed] 
100. Sheldrick, G. SHELXT-Integrated space-group and crystal-structure determination. Acta Cryst. A 2015, 71, 3-8. [CrossRef] [PubMed]

101. Sheldrick, G. Crystal structure refinement with SHELXL. Acta Cryst. C 2015, 71, 3-8. [CrossRef] [PubMed]

102. Hubschle, C.B.; Sheldrick, G.M.; Dittrich, B. ShelXle: A Qt graphical user interface for SHELXL. J. Appl. Cryst. 2011, 44, 1281-1284. [CrossRef] [PubMed] 